\title{
About 25-dihydroxycholecalciferol
}

\author{
Şinasi Özsoylu
}

Received: 22 December 2010 / Accepted: 25 January 2011 /Published online: 22 February 2011

(C) Springer-Verlag 2011

I enjoyed reading Liang and colleagues' research paper titled "Prevalence and risk factors for vitamin D deficiency among healthy infants and young children in Sacramento, California" in a recent issue of the journal [1]. In this well designed and nicely presented study, I would also have liked to see calcium, magnesium [2], phosphates, and cyclic AMP levels [2], to have other markers for 25hydroxycholecalciferol (25 OH CC) [3] deficiency, since neither parathormone nor bone specific alkaline phosphatase was found to be a definitive marker for this deficiency (Table 4).

I am also curious about the presence of hypercalcemia in children who had upper level of $25 \mathrm{OH} \mathrm{CC}$. Relatively low $25 \mathrm{OH}$ CC levels were found in only 4 out of 25 breastfed children. It would be interesting to know their mothers' breast milk $25 \mathrm{OH}$ CC levels [4]. Since $25 \mathrm{OH}$ CC levels were not found to be low in most of the breastfed children, it would be useful to know the bioavailability of breast milk $25 \mathrm{OH} \mathrm{CC}$ since we know the high bioavailability of iron in breast milk. Could there be a homologous situation with 25 $\mathrm{OH} \mathrm{CC}$ ?

\section{References}

1. Liang L, Chantry C, Styne DM, Stephensen CB (2010) Prevalence and risk factors for vitamin D deficiency among healthy infants and young children in Sacramento, California. Eur J Pediatr 169:13371344

2. Özsoylu Ș (1988) How long has cholecalciferol been called vitamin D? J Pediatr Gastr Nutr 6:303

3. Özsoylu Ș, Hanioğlu N (1977) Serum magnesium levels in children with vitamin D deficiency rickets. Turkish J Pediatrics 19:89-96

4. Özsoylu Ș, Hasanoğlu A (1981) 25-Hydroxycholecalciferol serum levels in breastfed infants. Arch Dis Child 56:118-119

Ş. Özsoylu ( $\bowtie)$

Pediatrics, Hematology and Hepatology,

Faith University Hospital,

Ankara, Turkey

e-mail: sinasiozsoylu@hotmail.com 